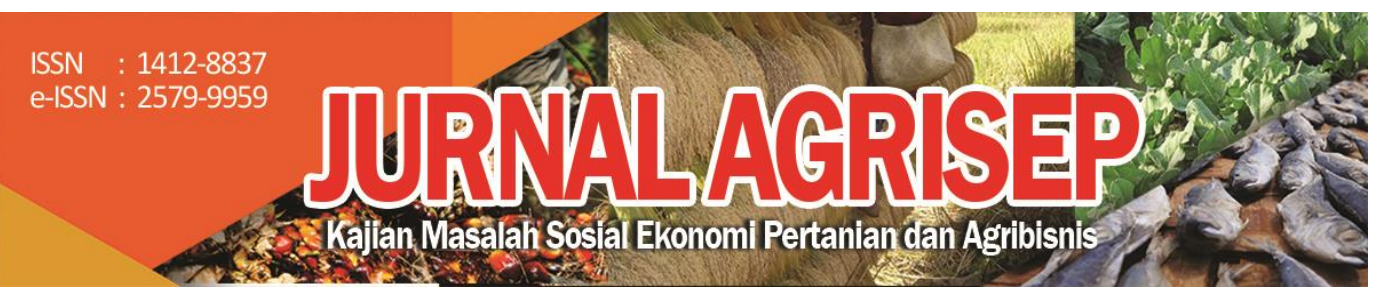

DOI: 10.31186/jagrisep.20.2.289-304

\title{
BRAND EQUITY DEVELOPMENT STRATEGY TO ENHANCE THE COMPETITIVENESS OF FOOD SMALL-MEDIUM ENTERPRISE'S (SMES): CASE STUDIES ON FUDIA-POLINELA AGRI-FOOD CENTRE)
}

\section{Strategi Membangun Equitas Merk Untuk Meningkatkan Daya Saing Ukm Pangan Lokal: Studi Kasus Pada Fudia-Polinela Agri-Food Center)}

\author{
Fitriani $^{1)} \square$, Sutarni ${ }^{2)}$, Bina Unteawati ${ }^{3)}$, Dewi Kania Widiawati4), Marlinda \\ Apriyani ${ }^{5}$, Dayang Berliana ${ }^{6}$ \\ 1,2,5,6) Agribisnis Pangan, Jurusan Ekonomi dan Bisnis, Politeknik Negeri \\ Lampung, Lampung, Indonesia \\ 3) Agribisnis, Jurusan Ekonomi dan Bisnis, Politeknik Negeri Lampung, \\ Lampung, Indonesia \\ 4) Manajemen Informatika, Jurusan Ekonomi dan Bisnis, Politeknik Negeri \\ Lampung, Lampung, Indonesia \\ Email: fitriani@polinela.ac.id
}

\begin{abstract}
The competitiveness of local agri-food needs through various marketing strategies. An essential part of the company's marketing strategy and tactics is recognizing product brand equity in the market. This study aims to identify brand entities, brand communication, and process to build Brand Equity toward local SMEs' competitiveness. A case study approach did at one of the SMEs in Bandar Lampung on the "FUDIACenter of Agri-Food Polinela," that produce FUDIA cake \& bakery. The research has conducted from April to July 2020. Data analysis used a qualitative descriptive approach using SWOT analysis and a brand development model for SMEs. The analysis results concluded that FUDIA's brand recognition is the initial stage. Development of the Fudia brand equity must take into account an existing market and expanding market share. Enhancement market share could trough sales force distribution. Develop more product variants of Fudia Cake \& Bakery based on the local source. Strengthen brand equity and develop a remarkable brand image program. Design and setting promotions systematic $\mathcal{E}$ massively is a priority.
\end{abstract}


Keywords: brand, equity, SMEs, competitiveness, strategy

\begin{abstract}
ABSTRAK
Pada kondisi pasar produk pangan menghadapi persaingan yang ketat, maka pelaku usaha perlu memperhatikan strategi pemasaran. Strategi dan taktik elemen pemasaran yang penting dilakukan adalah membangun ekuitas merk. Penelitian ini bertujuan mengidentifikasi brand entities, brand communication, dan proses membangun equitas merk oleh pelaku usaha UMK pangan lokal. Pendekatan studi kasus pada salah satu pelaku usaha dilakukan pada salah satu UKM di Bandar Lampung yaitu "FUDIA-Polinela Agri-Food Centre." Penelitian dilakukan dari bulan April s.d. Juli 2020. Analisis data menggunakan pendekatan statistik deskriptif dan kualitatif dengan pendekatan SWOT analysis. Hasil analisis menunjukkan bahwa posisi brand FUDIA berada pada posisi awal pengenalan. Pengembangan eikutas merk Fudia dapat dilakukan dengan menjaga dan memperluas wilayah pasar serta peningkatan pangsa pasar. Perluasan pasar dilakukan melalui tim sales taskforce dengan motorist. Pengembangan varian produk Fudia Cake E Bakery dengan bahan baku lokal menjadi kekuatan pembeda. Penguatan ekuitas merk dan rancangan program membangun citra merk diperlukan, juga promote secara sistematif dan berkelanjutan menjadi agenda utama.
\end{abstract}

Keywords: merk, ekuitas, UMKM, daya saing, strategi

\title{
BACKGROUND
}

In very competitive market conditions, business actors face fierce business competition. A business approach integrates market preference, product handling, internet marketing, and Local Value Chain (LVC) to build business sustainability (Fitriani et al. 2019). Marketing strategy is a management tool for improving the marketing performance of SMEs in dynamic environments. The combination of entrepreneurial orientation and marketing strategy will perform better marketing performance (Fadhilah, 2018). Market preference is the first step in determining the product that the consumer/market wants. Innovative packaging, labels, and brands (branding) are essential in differentiating goods or services (Fitriani et al., 2018, 2019; Unteawatiet et al., 2018). The packaging label displays complete information about the product, thereby increasing consumer appeal (Nugraha et al., 2017). Brand elements are trademarks that identify and differentiate brands (Simamora, 2018).

Therefore, business requires a comprehensive approach from all business lines to maintain their sustainability. Important factors that influence consumer purchases are availability (17.419\%), packaging $(14.237 \%)$, and price $(14.127 \%)$. The packaging of the product is crucial in product development. Price and taste are central stimuli that encourage

290 | Fitriani , Sutarni, Bina Unteawati, Dewi Kania Widiawati, Marlinda .... 
consumers to buy. The brand represents the image and values instilled by the company. It is strategic to enhance competitiveness in the era of global market competition, both large and small-scale businesses. The brand influences purchase interest and decision. It makes consumers chose easier when they have been facing many products available. Brands play an essential role in a business. Consumers can differentiate one product from another with brand existence. The more familiar a product is, the easier it is to market its product widely. The presence of technological advances needs to accelerate the changes in production and consumption patterns. The use of e-commerce in marketing products is a concern and requires intensive education so that SMEs can survive and continue to develop their business (Nugraha et al., 2017). Highly competitive products will create an image of quality, creative, and environmentally friendly, unique, and the market well accepts original products. The SME's benchmark to apply the brand strategy, especially SME's is significant (Susanti et al., 2018).

Develop brand equity in a business is a complex approach, especially for SMEs. Brand equity can help marketers focus, giving them away to interpret their past marketing performance and design their future marketing programs Keller (2003). Generally, SMEs do not consider yet and are not aware of brand equity development even though it's significant in enhancing business sustainability. MSEs are usually unable to meet market needs at a continuous level of volume, quality, time, and place (Fitriani et al., 2017; Novia et al., 2013; Pahlevi et al., 2014; Rangkuti et al., 2015; Sutarni et al., 2016; Unteawati et al., 2018a). SMEs face limitations in the mastery of modern production process technology due to inadequate capital resources and market access (Fitriani et al., 2017; Indarwanta et al., 2011; Ismono et al., 2011). The key success to enhance the competitive advantage for SMEs is synergizing business networks. The presence of a model hub-business between SMEs, universities, and business chain actors is essential. SMEs need to collaborate with university and business chain partners, especially in building innovation and technology adoption, also marketing expansion. It will increase the excellence and competitiveness in facing an increasingly competitive market.

A set of brand assets is called equity. Equity-linked to a brand, name, and symbol of product identities. Marketers can position their products in the market by maintaining brand equity determinants, hence influencing consumer choice (Vukasovic, 2016). In Aaker's conceptual framework, brand loyalty, brand awareness, perceived quality, brand associations, and "other proprietary brand assets" are identified as the sources of value to the firm and its customers (Shocker, 1993) (Aaker et al., 2004; Keller \& Aaker, 1998; Zablocki et al., 2018). 
The sustainability of SMEs depends on consumer's loyalty in consuming their products. An essential part of the company's marketing strategy is recognizing product brand equity in the market. As a new brand, it is significant to analyze how far the consumers' awareness of the Fudia brand. This study conducted to identify brand entities, brand communication, and process to build Brand Equity toward local SMEs' competitiveness in case of Fudia-Polinela Agri-Food Centre (PAC).

\section{METHOD}

The research has conducted from April to July 2020. A case study approach did at one of the SMEs in Bandar Lampung on the "FUDIA-Polinela Agri-Food Center (PAC)." PAC was a start-up business from the campus in 2019 as the output of the Intelectual Product Development Program fund by BRIN ministry. Pillars of digital marketing facilities and learning resources develop as Teaching Factory design. Teaching Factory based digital marketing will become learning resources in sustainable business for students and start-up businesses. PAC launched trademark FUDIA as a new brand. Registration of trademarks at DGIP. The trademark is registering for Intellectual Property Rights (application number is DID2019047488) (Fitriani et al., 2019). PAC business focuses on two-line products, i.e., food line (Fudia Cake \& Bakery and snack series) and digital marketing services (Androidbased FUDIA marketplace food-pedia application). PAC currently develop the distribution network with an on-shop and drop selling approach. Fudia's trademark became the main headline. Fudia and its brand equity carry the tagline "Encourage youth entrepreneurs and SMEs."

Sampling has designed by the snowball method. It starts from Politeknik Negeri Lampung (Polinela) community, where the business location takes place then spreads to the neighborhood. Questionaire set with google form application. Information associated with the brand identity, brand awareness, and market preference. Data analysis used a descriptive statistic and qualitative descriptive approach using SWOT analysis. The key expert respondent of SWOT analysis represented by the head of PAC, production and marketing leader division, head of Agribusiness Laboratory, and head of Economic and Business Department. The SWOT matrix develops with EFE Matrix (External Factor Evaluation) and IFE Matrix (Internal Factor Matrix). SWOT Matrix tool used to compile the company's strategic factors is the SWOT method (Zuhdi et al, 2020). 


\section{RESULT AND DISCUSION}

\section{Fudia Brand Identity}

The building, measuring, and managing brand equity has become a top priority for many companies. Polinela Agri-food Center (PAC) launched brand "FUDIA" for the main line business on food processed production. PAC established in 2019 with various snack food production. PAC developed FUDIA cake and bakery division since January 2020. The capacity production reached 9.250 pieces per month with the amount of sales value (omzet) attaint to $\mathrm{Rp} \mathrm{50,8} \mathrm{million} \mathrm{per} \mathrm{month.} \mathrm{The} \mathrm{omzet} \mathrm{One} \mathrm{crucial}$ strategic branding decision is the proper role of the corporate or company brand name. All respondents are well known Brand Fudia. The respondent's demographic character showed that women dominantly more than men. They represented by woman $69,2 \%$. It condition support by the fact that woman hold the main role in food consumption decision. Based on the education background, respondent were dominantly by higher educational level (Figure 1). It means that the consumers of Fudia product is well educated.

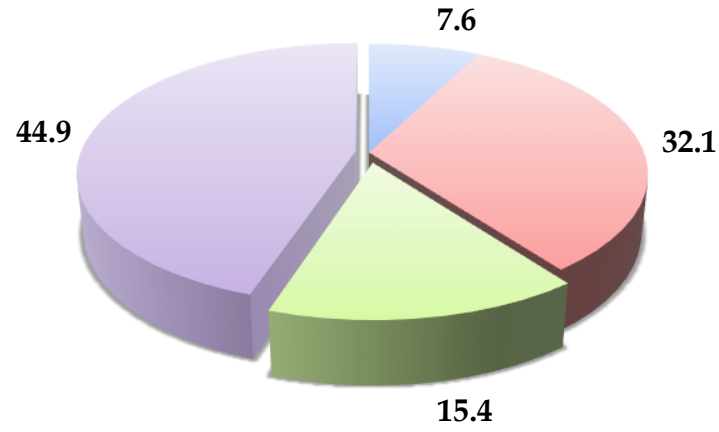

Yunior High School Senior High School Undergraduated $₫$ Postgraduated

Figure 1.

Education background of respondent (\%)

Figure 1 performed that an excellent educational background (60\%) represents got access to higher education. The education level determined the ability in any kind of food consideration for theirself and the member of family. The better education will support the better decision for the best consumption pattern for the family. In Figure 2 it showed the age level of the respondent. The age of respondent describes the level of Fudia 
consumers. The range of consumers' age is necessary in segmenting strategy action. Respondents are mostly at a younger age (under 40 years old). They represent the millennium generation.

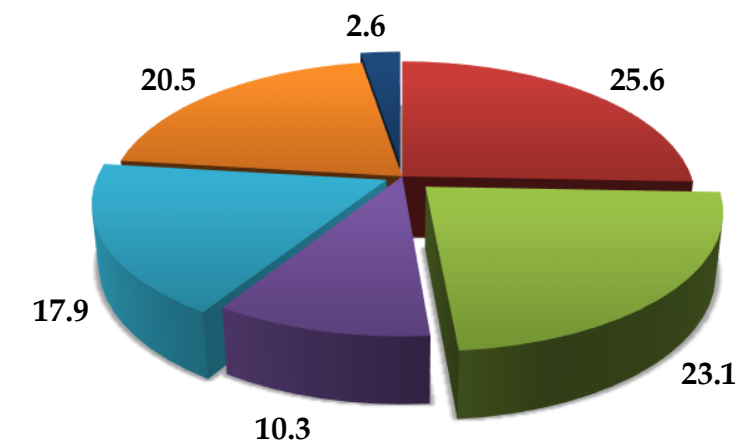

$\square$ 10-15 $\square$ 16-20 $\square 21-25 \square 26-30 \quad 30-40 \backsim 40-50 \square>50$

Figure 2.

Age proportion of Fudia's consumers respondent (\%)

The income level of respondents dominantly by more than two million per month reached $55,1 \%$ of respondent (Figure 3 ). The fact that the income of consumers was higher than the standard of minimum regional payment, describes the consumers' purchase ability. The ability of consumers' purchasing is realy important to reach the selling transaction deal.

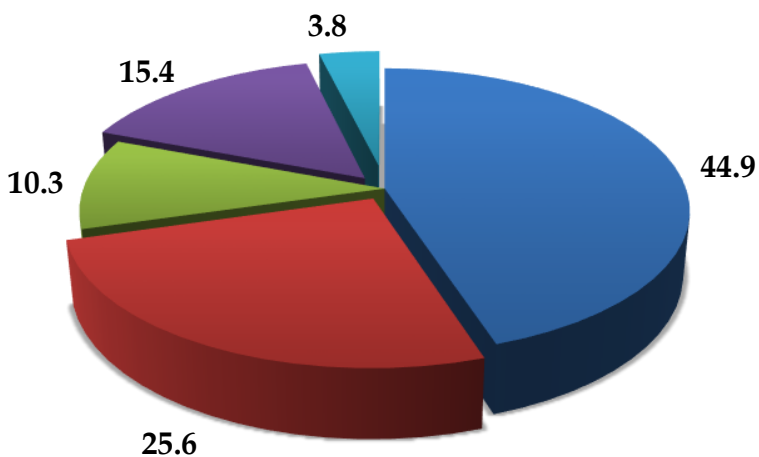

2 million $\quad$ 2-4 million $\quad$ 4-6 million $\quad 6-10$ million $\quad>10$ million

Figure 3.

Income level of respondent (\%)

294 | Fitriani, Sutarni, Bina Unteawati, Dewi Kania Widiawati, Marlinda .... 
Fudia has designed with a set of attributes. The brand equity of Fudia describes fulfilling the requirements for a good brand. Useful brand details are: easy to remember, meaningful, likable, transferable, protectable, easy to remember, meaningful, and pleasant. The explanation about Brand Fudia identity as follows:

1. Fudia is easy to remember. Fudia is a short phrase. Easy to said and remarkable.

2. Fudia is a meaningful brand. The brand has associated meaning with food.

3. Fudia is likable. It represents the likeableness thing. Fudia creates names, logos, and symbols.

4. Fudia is transferable. Fudia is accessible to everyone.

5. Fudia is pleasant. Fudia brand describes a lovely thing. Fudia has a jingle.

6. Fudia is protectable. The brand registered as intellectual property right DGIP

Building brand equity requires the following steps: (1) initial choice of brand elements or brand identities that make up a brand (such as brand names, logos, symbols, characters, brand spokespersons, slogans, jingles, etc.) packaging and signage), (2) products and services and all marketing activities that accompany marketing programs and (3) other associations that are transferred indirectly to the brand by associating it with another entity (someone, place or something) (Simamora, 2018). (Šerić, 2017) noted that de Chernatoney and McDonald (2006) indicated that the brand name is the one that receives the most attention from consumers among all the marketing variables. Further, Aaker (1991) stated that the brand name and what it represents are the essential assets of brand equity, whereas Keller (2003) stressed that brand name is the most central of all brand elements. Strong and favorable associations that exist for a specific brand name are unique to the brand, imply superiority over other brands (Keller, 1993), and often depend on the marketing mix adopted by a company (Arnett et al., 2003). Managers should first build brand awareness as a means of improving perceived quality and building positive brand associations. Any influential drivers, including marketing mix efforts, should be undertaken to increase the level of familiarity or recall. Fudia brand equity elements based on (Roşca, 2018):

(1) Brand Awareness of Brand Fudia.

Brand awareness is a measure of how many potential customers know a brand. A common strategy in marketing and advertising could set to increase the level of brand awareness. Buyers are much more comfortable 
with a known product than with a new product. All respondent has known Fudia well. They have consumed Fudia with the reason for the benefit of the product. Mostly, consumer's agree $(65,4 \%)$ and very agree $(21,8 \%)$ that Fudia's product give benefit as their desire. It give the advantage in fulfilling the energy need (Figure 4).

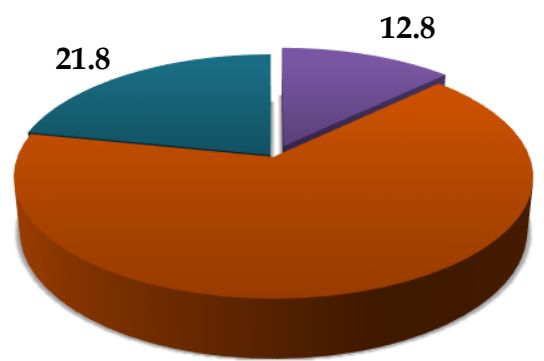

65.4

Very Disagree $\square$ Disagree $\square$ Maybe $\quad$ Agree $\square$ Very agree

Figure 4 .

Benefit awareness of Fudia brand (\%)

(2) Brand Loyalty.

Brand loyalty defined as the extent to which a customer shows a positive attitude towards a brand, has a commitment to a particular brand, and intends to continue to buy it in the future. It is closely related to consumer satisfaction, and consumer complaint behavior is the concept of brand loyalty. The survey revealed that most of the respondents were agree $(51,3 \%)$ and very agree $(43,6)$ satisfied with consuming Fudia products (Figure 5). 


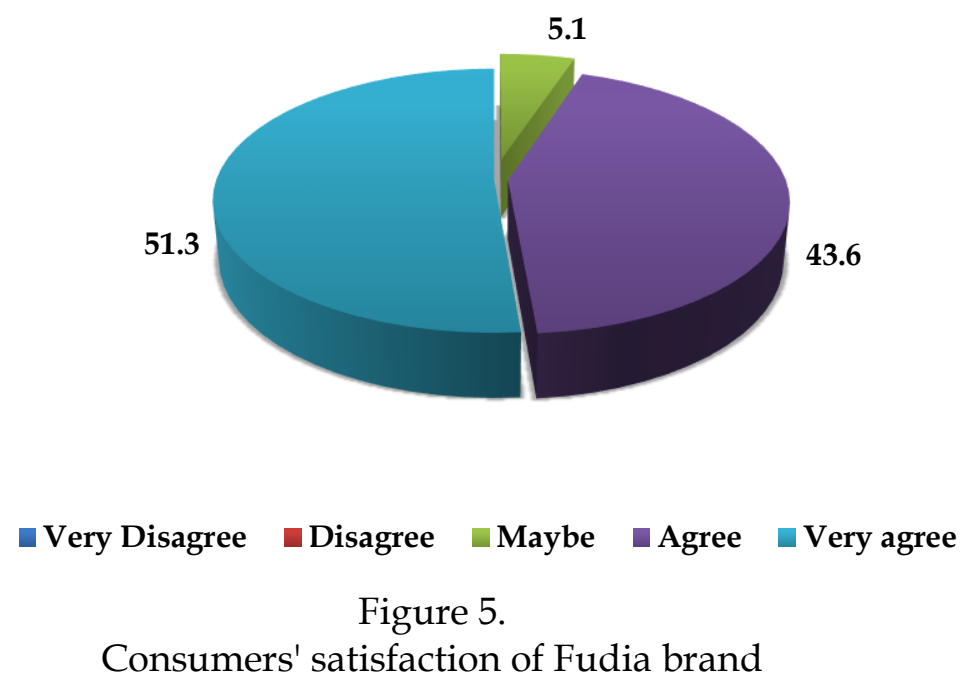

(3) Brand Association (Brand Association).

Brand association is the perception and image of people with a particular brand. Consumers' opinion agree $(57,7)$ and very agree $(38,5 \%)$ that Fudia brand equity has accosiated with the term "Food" and "Foodpedia, and android marketplace platform." Figure 6 displayed Fudia brand association.

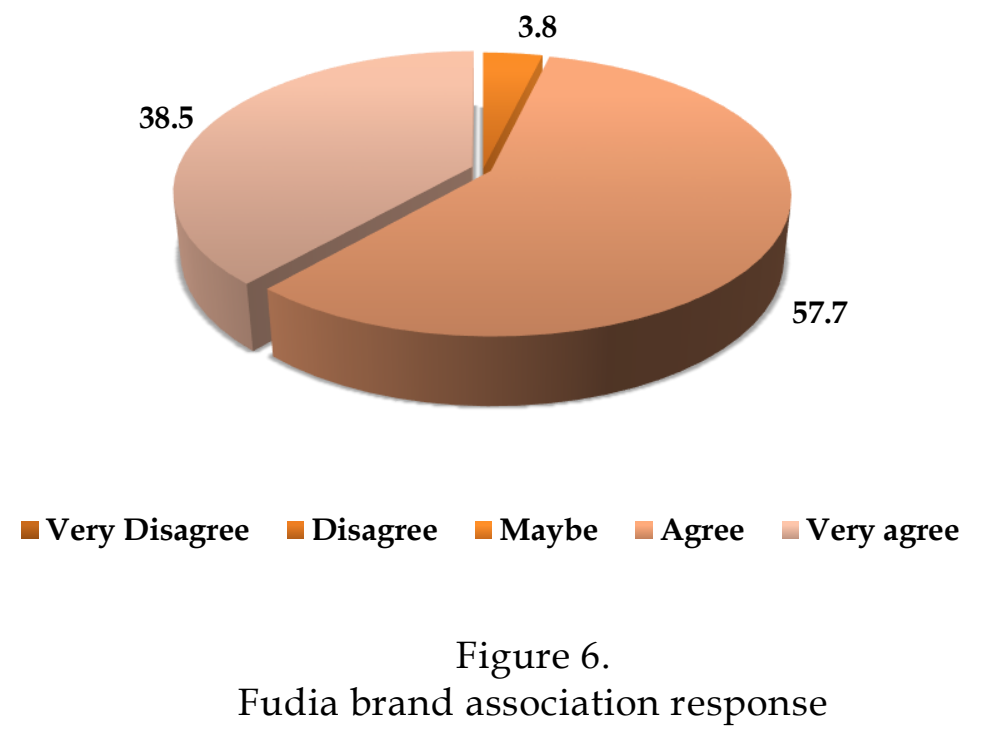

AGRISEP Vol. 20 No. 2 September 2021 Hal: 289 - 304 | 297 
(4) Perceived Quality.

The perceived quality is part of the buyer's brand image based on reality and experience. The idea of perceived quality is set on perceptions born of a company's reputation, words, media coverage, and other indirect information sources. Respondent agrees $(48,7 \%)$ and strongly agree $(48, \& \%)$ to refer the Fudia product to their colleagues and community (Figure 7). Colleagues and community referal is important as an effective spreading product existing information for broading promotion.

2.6

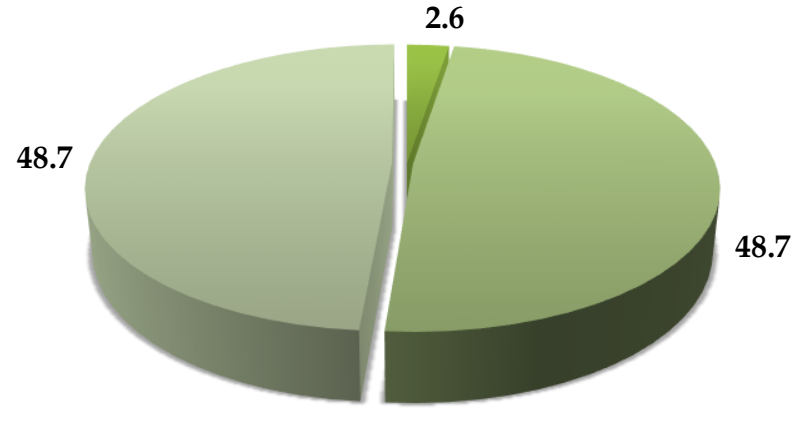

Very Disagree $\square$ Disagree $\square$ Maybe $\quad$ Agree $\square$ Very agree

Figure 7.

Respondent referral willingness to colleagues and community

(5) Core values.

Core values are valued, upheld, carried out, and are the organization's soul. Generally, a core value is an adjective and comes with an explanation. Brand Fudia develops by PAC with the spirit to strengthen business and inspire the young and SMEs. Business sustainability is a priority. Respondent agrees $(48,7 \%)$ and strongly agree $(48, \& \%)$ that Fudia value in hamonizing costumers' food choice. The Fudia brand is here with the hope of harmonizing consumers' food choices (Figure 8) 


\section{6}
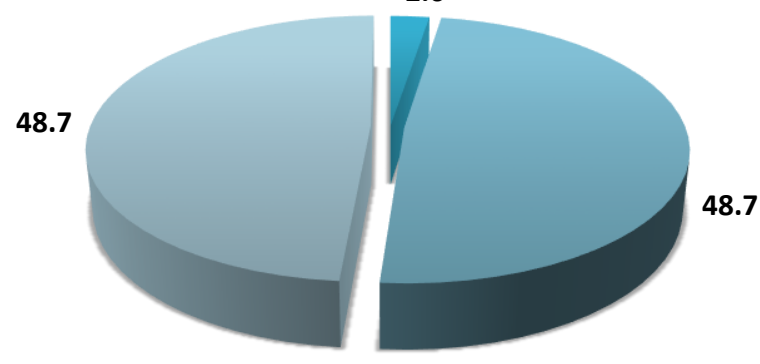

$\square$ Very Disagree $\square$ Disagree $\square$ Maybe Agree Very agree

Figure 8 .

Fudia value harmonizing consumers' food choices (\%)

Branding offers to gain an identity, evolving meaning, and project an image conducive to building brand equity. The branding role extends between offering with differentiating its offer from its competitors and positioning it in the customers' minds (El-Ansary, 2006). PAC set a promotion package to develop Fudia brand equity. The promotion kind has been categorized as below the line (BTL) and above the line (ATL). Fudia brand promotion in BTL used posters, banner, stickers, catalogs, discount programs, free trials, expo, and sponsorship. Massive publicity did with social media platforms, i.e., Instagram (@fudia_bakery), WhatsApp, youtube, and marketplace (63\%) (Figure 9). As a fact, social media is that it's a mixture of BTL and ATL (Rachel Miller: https://www.marketingdonut.co.uk/).

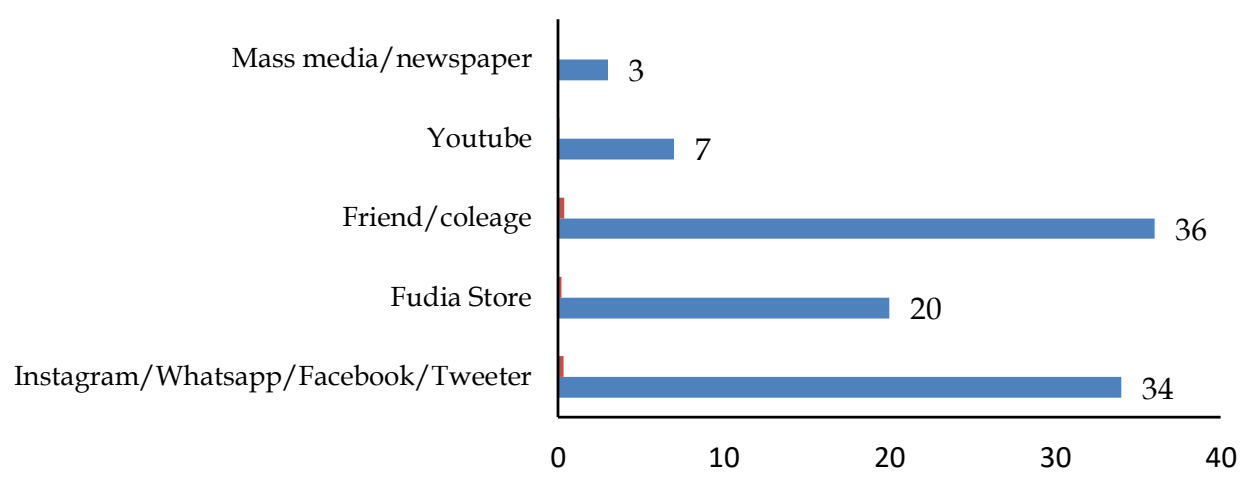

Figure 9.

The media sources of Fudia brand known by consumers (\%) 
The most popular promotional and marketing media channels are email $(82 \%)$, social media (62\%), online advertising (50\%), and direct mail $(46 \%)$. The highest promotional and marketing media channels are using social media (66\%), exhibitions and events (61\%), online advertising (59\%), and direct mail (57\%) (Royal Mail Group, 2016). According to TEMASEK and Google's research, Indonesian e-commerce is increasing, and the growing use of the internet in Indonesia. In 2015, there were 92 million internet users in Indonesia, with 18 million online shoppers. By 2025, 119 million people are predicted to become online buyers in Indonesia. The value of Indonesia's ecommerce market is expected to reach $\$ 81$ billion. Fudia recognition based on response showed that most $(73 \%)$ respondents have known from Fudia cake \& bakery existence.

\section{Fudia Brand Strategy}

Design brand equity strategy for new SMEs needs to comprehend information. Analysis of the internal and external conditions of SMEs is a fundamental step in capturing business existences. SWOT analysis stages start from identifying all matters relate to internal conditions (strengths and weaknesses as Internal Factors Strategy (IFAS)) and external conditions (opportunities and threats as External Factors Strategy (EFAS)). Next step is determination of inhibiting and supporting factors. Then determination of alternative activities and formulation of the objectives of each activity.

Identification of the situation and state of the IFAS and IFAS market is important step. The information of EFAS and IFAS condition then will be plotting at the SWOT Matrix. SWOT analysis has carried out to formulate a problem-solving framework at hand (Figure 10).

Based on the SWOT matrix strategy, then priority strategy set as recommodation in building Fudia brand existence. The strategy should take into account the condition below:

a. Maintaining an existing market and expanding market share through a remarkable brand image program and interactive promotion massively

b. Enhancement of market share through sales force distribution

c. Strengthen the brand equity program through social media branding actively

d. Set an attractive price and personal selling 


\begin{tabular}{|c|c|c|}
\hline INTERNAL ( I F E) & $\begin{array}{l}\text { Opportunity } \\
\text { - The positive response } \\
\text { from consumers } \\
\text { because both brands } \\
\text { already have an image } \\
\text { with good quality in the } \\
\text { minds of consumers. } \\
\text { - Digital marketing } \\
\text { technology massive } \\
\text { blom } \\
\text { Market territory } \\
\text { expands both field and } \\
\text { marketplace } \\
\text { Income enhancement of } \\
\text { consumer and also the } \\
\text { lifestyle }\end{array}$ & $\begin{array}{l}\text { Treath } \\
\text { - } \quad \text { Competitor } \\
\text { - } \quad \text { pew other subtitue } \\
\text { products } \\
\text { - } \quad \text { Products are easy to } \\
\text { imitate } \\
\text { - Competitors release } \\
\text { more innovative } \\
\text { new products } \\
\text { - } \text { Price competition } \\
\text { with competitors } \\
\text { Covid } 19 \text { pandemic }\end{array}$ \\
\hline $\begin{array}{l}\text { Strength } \\
\text { - Fudia has matching } \\
\text { function as food } \\
\text { product. } \\
\text { The property right of } \\
\text { Fudia registered } \\
\text { - Corporate value be the } \\
\text { greatest business } \\
\text { Production technology } \\
\text { in medium-scale up with } \\
\text { many Varian bakery } \\
\text { Fudia label and package } \\
\text { are Unix and attractive. } \\
\text { Network distribution set } \\
\text { as solid motorist } \\
\text { salesforce }\end{array}$ & $\begin{array}{l}\text { S-O Strategy } \\
\text { - } \quad \text { Maintaining an existing } \\
\text { market and expanding } \\
\text { market share } \\
\text { - } \quad \text { Develop a remarkable } \\
\text { brand image program } \\
\text { - } \text { Develop more product } \\
\text { variants of Fudia Cake } \\
\text { \& Bakery based on local } \\
\text { source }\end{array}$ & 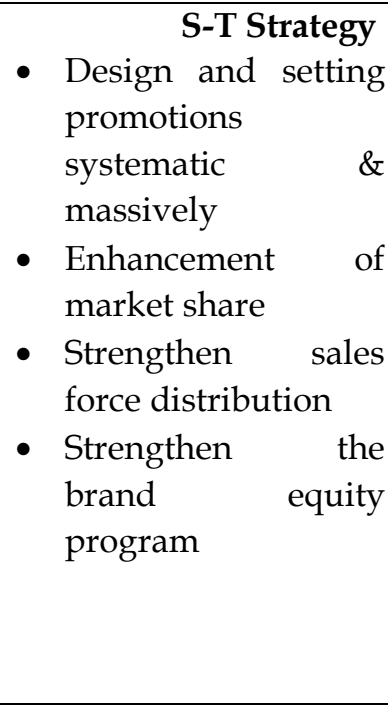 \\
\hline $\begin{array}{l}\text { Weakness } \\
\text { - Fudia still new in the } \\
\text { business } \\
\text { - Segmentation is not } \\
\text { widespread yet. } \\
\text { - Promotion is not } \\
\text { massive yet. } \\
\text { - Unattractive price. }\end{array}$ & $\begin{array}{l}\text { - Intensive promotion of } \\
\text { - Social media branding } \\
\text { - Optimize the scale-up e } \\
\text { - Attractive price and pe }\end{array}$ & $\begin{array}{l}\text { T Strategy } \\
\text { ia brand equity } \\
\text { ely } \\
\text { omy production } \\
\text { al selling }\end{array}$ \\
\hline
\end{tabular}

Figure 10.

SWOT Matrix of Brand Fudia development strategy 


\section{CONCLUSION AND SUGGESTION}

\section{Conclusion}

1. Development of the Fudia brand equity must take into account an existing market and expanding market share. Enhancement market share could trough sales force distribution.

2. Development more product variants of Fudia Cake \& Bakery based on local source

3. Strengthen brand equity and develop a remarkable brand image program. Design and setting promotions systematic \& massively is a priority.

\section{Suggestion}

Based on the conclusion, development the brand equity is very strategic to enhance the competitiveness of business sustainability. Therefore, SMEs must pay more action in creating an attractive promotion program. It also important to consider the chain of promotion media. Digital marketing with marketplace platform, and athe social media networking should be the priorty.

\section{REFERENCES}

Aaker, D. A., Blahut, S. A., Evans, W. D., Price, S., \& Ulasevich, A. 2004. A confirmatory test of a higher order factor structure: Brand equity and the truthsm campaign. Social Marketing Quarterly. 10(1): 3-15

El-Ansary, A. I. 2006. Marketing strategy: Taxonomy and frameworks. European Business Review. 18(4), 266-293

Fadhilah, M. 2018. The Mediating Role of Marketing Strategy Between The Entrepreneurial Orientation and The Marketing Performance. Prosiding Business and Economics Conference In Utilizing of Modern Technology. 166176.

Fitriani, F., Unteawati, B., \& Fatih, C. 2017. Local Processed Food Industry Based Cassava in Improving Rural Economy. In I. Agus Haryanto, M. Ir Sugeng Triyono, S. Waluyo, I. Sandi Asmara, Ms. Diding Suhandy, Ma. Mareli Telaumbanua, ... T. Wahyu Saputra (Eds.), "Strengthening Food and Feed Security and Energy Sustainability to Enhance Competitiveness" 
(pp. 155-158). Retrieved from http://repository.lppm.unila.ac.id/7898/1/2018 Dwi Cahyani.pdf

Fitriani, F., Unteawati, B., Mutaqin, Z., \& Sutarni, S. 2018. The Mapping of Agroindustry Based on Cassava. 3th International Conference on Biomass, 12. https://doi.org/10.1088/1755-1315/209/1/012019

Fitriani., Sutarni., Haryono, D., Ismono, H., \& Lestari, D. A. H. 2017. Pertanian Perdesaan Lampung: Peluang dan Tantangan. JoFSA Journal of Food System \& Agribusiness. 1(2): 43-52

Fitriani, Sutarni, Unteawati, B., \& Widyawati, D. K. 2019. Polinela Smart MarketPlace untuk Penguatan Jejaring Kluster Rantai Pasok dan Bisnis Berkelanjutan Polinela Smart Market-Place for Streghthen Sustainable Supply Chain Network. Prosiding Seminar Nasional Pengembangan Teknologi Pertanian IPTEKS, (November): 1-10

Indarwanta, D., \& Pujiastuti, E. E. 2011. Kajian Potensi (Studi Kelayakan) Pengembangan Agroindustri di Desa Gondangan Kecamatan Jonalan Klaten. Administasi Bisnis. 8(2): 1-13.

Ismono, H., Arifin, B., \& Fitriani. 2011. Implikasi INPRES No. 1 Tahun 2006 tentang Bahan Bakar Nabati Terhadap Kondisi Bahan Baku Industri Gula di Propinsi Lampung. PANGAN. 20(1): 163-175.

Keller, K. L., \& Aaker, D. A. 1998. The Impact of Corporate Marketing on a Company's Brand Extensions. Corporate Reputation Review. 1(4): 356-378

Novia, W., Zakaria, W. A. Z., \& Lestari, D. A. H. 2013. Analisis Nilai Tambah

Dan Kelayakan Pengembangan Agroindustri Beras Siger. JIIA (Jurnal Ilmu-Ilmu Agribisnis). 1(3): 210-217.

Nugraha, H. S., Ariyanti, F., \& Darwanto. 2017. Penerapan Branding Pada Ukm Makanan Ringan Di Kabupaten Jepara. Jurnal Administrasi Bisnis. 6(1): 16-23

Pahlevi, R., Zakaria, W. A., \& Kalsum, U. 2014. Analisis Kelayakan Usaha agroindustri Kopi Luwak di Kecamatan Balik Bukit Kabulapen Lampung Barat. Jurnal Ilmu-Ilmu Agribisnis. 2(1): 48-55

Rangkuti, K., Mardhiyah, A., \& Putr, A. D. (2015). Analisis Nilai Tambah Keripik Singkong pada Kelompok Usaha Keluarga (KUK) Desa Sipare-Pare. Agrium. 19(2): 116-121

Šerić, M. 2017. Relationships between social Web, IMC and overall brand equity. European Journal of Marketing. 51(3): 646-667 
Shocker, A. D. 1993. New books in review. 1963. Journal of Marketing Research. 30(2): 256-258

Simamora, B. 2018. Branding strategy. In Business Horizons. https://doi.org/10.1016/s0007-6813(96)90062-2

Susanti, E., Oskar, D. P., Putra, U., \& Yptk, I. 2018. Strategi Branding Dalam Membangun Ekuitas Merek UMKM (Studi Kasus: Pusat Oleh - Oleh Kota Padang). IKRAITH EKONOMIKA. 1(2): 116-130

Sutarni, Fitriani, \& Unteawati, B. 2016. Analisis Rugi Laba Jangka Pendek Usaha Agribisnis Perikanan Air Tawar Kolam Khusus Ikan Patin di Kabupaten Lampung Tengah Analysis of Short-Term Income Freshwater Fishery Agribusiness Specialty Swimming Catfish in Central Lampung. (September), 315-326.

Unteawati, B., Fitriani, \& Fatih, C. 2018. Consumer' s Market Analysis of Product Cassava. In P. E. Hambali, 2. Prof. Yandra Arkeman, 3. Dr. Dwi Setyaningsih, 4. Dr. Mujizat Kawaroe, 5. Dr. Yohanes Aris Purwanto, 6. Dr. Titi Candra Sunarti, ... 8. Dr. Obie Farobie (Eds.), 2nd International Conference on Biomass: Toward Sustainable Biomass Utilization for Industrial and Energy Applications (pp. 012033-012042). https://doi.org/10.1088/1755-1315/141/1/012033

Vukasovic, T. 2016. A conceptual framework for understanding consumer based brand equity. In MakeLearn and TIIM Joint International Conference: Managing Innovation and Diversity in Knowledge Society Through Turbulent Time (pp. 991-997). Retrieved from https://ideas.repec.org/h/tkp/mklp16/991-997.html

Zablocki, A., Schlegelmilch, B., \& Schant, E. 2018. Customer-Based Brand Equity in the Digital Age: Development of a Theoretical Framework: An Abstract. Back to the Future: Using Marketing Basics to Provide Customer Value, Developments in Marketing Science, 741-742. https://doi.org/10.1007/978-3-319-66023-3_237

Zuhdi, S., Rainanto, B. H., \& Apriyani, D. 2020. Analysis of Co-Branding Strategy to Improve Company's Competitive Power (Case Study on Walls Selection Oreo). Anvance in Economics, BUsiness and Management Research, 143, 146-149. https://doi.org/10.2991/aebmr.k.200522.030

304 | Fitriani, Sutarni, Bina Unteawati, Dewi Kania Widiawati, Marlinda .... 